\title{
BIBLIOGRAPHICAL ABBREVIATIONS
}

(see also general abbreviations given inside the front cover)

$\begin{array}{ll}\text { AA } & \text { Archäologischer Anzeiger } \\ \text { AAA } & \text { Athens Annals of Archaeology } \\ \text { ADelt } & \text { Archaiologikon Deltion (Chr = Chronika) } \\ \text { AE } & \text { Archaiologike Ephemeris } \\ \text { AEMTH } & \text { Archaiologiko Ergo ste Makedonia kai Thrake } \\ \text { AJA } & \text { American Journal of Archaeology } \\ \text { AR } & \text { Archaeological Reports } \\ \text { AW } & \text { Antike Welt } \\ \text { CRAI } & \text { Comptes rendus de l'académie des inscriptions et belles lettres } \\ \text { DOP } & \text { Dumbarton Oaks Papers } \\ \text { Ist. Mitt. } & \text { Mitteilungen des Deutschen Archäologisches Instituts } \\ \text { JÖAI } & \text { Jahrbuch des Österreichischen Archäologisches Instituts } \\ \text { JRA } & \text { Journal of Roman Archaeology } \\ \text { PAE } & \text { Praktika tes en Athenais Archailogikes Etaireias } \\ \text { RA } & \text { Revue archéologique } \\ \text { REA } & \text { Revue des études anciennes } \\ \text { REG } & \text { Revue des études grecques }\end{array}$


THE HELLENIC SOCIETY

The Society for the Promotion of Hellenic Studies was founded in 1879 to advance the study of Greek language, literature, history, art and archaeology in the Ancient, Byzantine and Modern periods. Membership is open to all, and there is a reduced rate for students. The Society has four main areas of activity: Publications: The Journal of Hellenic Studies was first issued in 1880 and is internationally recognized as one of the foremost periodicals in the field of Classical scholarship. It contains articles on a wide variety of Hellenic topics, and reviews of recent books of importance to Greek studies. All members receive both the Journal and its supplement Archaeological Reports. The Joint Library: the Library is maintained jointly with the Society for the Promotion of Roman Studies and in association with the Institute of Classical Studies of London University. Members resident in or visiting the United Kingdom may borrow the Societies' books and slides, either in person or by post. Meetings: the Society arranges an annual lecture series in London, holds occasional receptions and other meetings, and helps to arrange lectures in collaboration with the various local branches of the Classical Association. Grants: the Society aims to help those engaged in Hellenic Studies at all levels, and to this end it makes grants of various kinds to undergraduates, graduates and junior researchers. Institutions (typically, but not exclusively, universities) may apply for a grant from the Council of the Society, to fund academic conferences and other events. Schools may apply for grants from the Schools Sub-committee of the Society; details of all grants are available from the Secretary.

Current subscription rates and further details are given in a Prospectus available from the Society office or the Joint Library. For further information please contact: The Secretary, Hellenic Society, Senate House, Malet Street, London WC1E 7HU (tel. 020-7862-8730, fax 020-7862-8731, e-mail hellenic@sas.ac.uk).

\section{THE BRITISH SCHOOL AT ATHENS}

The British School at Athens (founded in 1886) provides facilities for research and travel in Greece for students of its history, art, archaeology, language and literature of all periods. Its premises in Athens consist of a residential hostel, an excellent library, map and archive collections, a small museum and the Fitch Laboratory, a centre for science-based archaeology. The School also maintains a residential 'dig-house' at Knossos in Crete, which serves as a base for excavations and for students engaged in research. Membership is open to senior scholars in post and retired, postgraduate research students, and teachers of classics and related subjects in schools, undergraduates and participants in fieldwork in Greece. Other persons working in the field of Hellenic studies may be admitted at the discretion of the Director. Subscribing members are entitled to receive School publications at favourable rates.

The School conducts an annual programme of fieldwork and is currently engaged in excavations at Knossos, Palaikastro and Sparta, and field surveys in Crete, Kythera and Laconia, while the study of material from excavations for publication continues throughout the year. In September a Summer School on the Archaeology and Topography of Ancient Greece, with a programme of lectures and visits to sites and museums, is offered to undergraduate students. In alternate years a two-week course of lectures and site visits is available to teachers of classics and classical civilizations in UK schools, in association with JACT. A postgraduate course on 'Athens and Attica' (of eight weeks duration, January to March) is offered in alternate years; further details are available from the London office.

Studentships and awards are available annually for postgraduate research in Greece, and short-term bursaries (up to three months) are offered to Greek and Cypriot graduates for study at British institutions.

The Annual of the British School at Athens publishes reports of the School's major fieldwork projects and articles on a wide range of Hellenic subjects. The School also publishes jointly with the Society for the Promotion of Hellenic Studies 'Archaeology in Greece'(in Archaeological Reports), an up-to-date account of current archaeological fieldwork. The series of Supplementary Volumes, including the Fitch Laboratory Occasional Papers and BSA Studies, consists of detailed publications of major School excavations and related topics. The British School at Athens: the First Hundred Years marked its centenary in 1986.

Details of membership, lectures, courses, subscription rates and available publications may be obtained from the Secretary of the London office: British School at Athens, Senate House, Malet Street, London WC1E 7HU (tel. 020-7862-8732, fax 020-7862-8733, e-mail: bsa@sas.ac.uk).

\section{ARCHAEOLOGICAL REPORTS AND THE AMERICAN JOURNAL OF ARCHAEOLOGY}

Archaeological Reports is available to subscribers to the American Journal of Archaeology at a special rate of $£ 11$ or US $\$ 22$. This is the result of an agreement between the Council of the Hellenic Society, the Managing Committee of the British School at Athens and the Governing Body of the Archaeological Institute of America. $A R$ is not normally obtainable separately on a subscription basis and subscribers to the $A J A$ who wish to take advantage of this arrangement should write to the Secretary, The Hellenic Society, Senate House, Malet Street, London WC1E 7HU, UK. Back-numbers of $A R$ are also available, at a cost of $£ 8$ or US $\$ 16$ per volume.

\section{THE INSTITUTE OF CLASSICAL STUDIES PHOTOGRAPHIC ARCHIVE}

The Institute of Classical Studies has an archive of photographs of a large number of the Greek dramatic monuments listed by Professor T.B.L. Webster in his BICS Supplements on Old and Middle Comedy, New Comedy, and Tragedy and Satyr Play. The catalogues of the monuments illustrating Old and Middle Comedy and New Comedy have been revised and considerably enlarged by Professor J.R. Green and Professor Axel Seeberg. Monuments Illustrating Old and Middle Comedy is available as BICS Supplement 39, and Monuments Illustrating New Comedy as BICS Supplement 50. 